\title{
"In-Situ Sampling and Characterization of Naturally Occurring Marine Methane Hydrate Using the D/V JOIDES Resolution."
}

\section{TECHNICAL PROGRESS REPORT \#9}

Type of Report: Quarterly

Reporting Period Start Date: October 1, 2003

Reporting Period End Date: December 31, 2003

Principal Authors: Dr. Frank R. Rack, Drs. Gilles Guerin and David Goldberg, and the ODP Leg 204 Shipboard Scientific Party

Date Report Issued: February 2004

\section{COOPERATIVE AGREEMENT DE-FC26-01NT41329}

Frank R. Rack (Joint Oceanographic Institutions; 1201 New York Ave., NW; Suite 400; Washington, DC, 20005; Tel: (202) 232-3900, ext. 1608;

Email: frack@joiscience.org);

Gilles Guerin and David Goldberg (Lamont-Doherty Earth Observatory of Columbia University; Route 9W, Palisades NY 10964); and the

ODP Leg 204 Shipboard Scientific Party* (see attached list of participants provided at the end of this report) 


\section{DISCLAIMER}

This report was prepared as an account of work sponsored by an agency of the United States Government. Neither the United States Government nor any agency thereof, nor any of their employees, makes any warranty, express or implied, or assumes any legal liability or responsibility for the accuracy, completeness, or usefulness or any information, apparatus, product, or process disclosed, or represents that its use would not infringe privately owned rights. Reference herein to any specific commercial product, process, or service by trade name, trademark, manufacturer, or otherwise does not necessarily constitute or imply its endorcement, recommendation, or favoring by the United States Government or any agency therof. The views and opinions of authors expressed herein do not necessarily reflect those of the United States Government or any agency thereof.

The international Ocean Drilling Program is managed by Joint Oceanographic Institutions, Inc., under contract with the U.S. National Science Foundation. Funding for the program is provided by the following agencies:

Australia/Canada/Chinese Taipei/Korea Consortium for Ocean Drilling Deutsche Forschungsgemeinschaft (Federal Republic of Germany) Institut National des Sciences de l'Univers-Centre National de la Recherche Scientifique (INSU-CNRS; France)

Ocean Research Institute of the University of Tokyo (Japan)

National Science Foundation (United States)

Natural Environment Research Council (United Kingdom)

European Science Foundation Consortium for Ocean Drilling (Belgium, Denmark, Finland, Iceland, Ireland, Italy, The Netherlands, Norway, Portugal, Spain, Sweden, and Switzerland)

Marine High-Technology Bureau of the State Science and Technology Commissions of the People's Republic of China

Any opinions, findings, and conclusions or recommendations expressed in this report are those of the author(s) and do not necessarily reflect the views of the National Science Foundation, the participating agencies, Joint Oceanographic Institutions, Inc., Texas A\&M University, or Texas A\&M Research Foundation. 


\begin{abstract}
The primary accomplishments of the JOI Cooperative Agreement with DOE/NETL in this quarter were that: (1) Leg 204 scientific party members presented preliminary results and operational outcomes of ODP Leg 204 at the American Geophysical Union Fall meeting, which was held in San Francisco, CA; and, (2) a report was prepared by Dr. Gilles Guerin and David Goldberg from Lamont-Doherty Earth Observatory of Columbia University on their postcruise evaluation of the data, tools and measurement systems that were used for vertical seismic profiling (VSP) experiments during ODP Leg 204. The VSP report is provided herein.
\end{abstract}

Intermediate in scale and resolution between the borehole data and the 3-D seismic surveys, the Vertical Seismic Profiles (VSP) carried during Leg 204 were aimed at defining the gas hydrate distribution on hydrate ridge, and refining the signature of gas hydrate in the seismic data.

VSP surveys were attempted at five sites, following completion of the conventional logging operations. Bad hole conditions and operational difficulties did not allow to record any data in hole $1245 \mathrm{E}$, but vertical and constant offset VSP were successful in holes 1244E, 1247B and 1250F, and walk-away VSP were successfully completed in holes $1244 \mathrm{E}, 1250 \mathrm{~F}$ and $1251 \mathrm{H}$. Three different tools were used for these surveys.

The vertical VSP provided the opportunity to calculate interval velocity that could be compared and validated with the sonic logs in the same wells. The interval velocity profiles in Holes 1244E and 1247B are in very good agreement with the sonic logs.

Information about the Leg 204 presentations at the AGU meeting are included in a separate Topical Report, which has been provided to DOE/NETL in addition to this Quarterly Report.

Work continued on analyzing data collected during ODP Leg 204 and preparing reports on the outcomes of Phase 1 projects as well as developing plans for Phase 2. 


\section{TABLE OF CONTENTS}

$\begin{array}{ll}\text { Disclaimer } & 2\end{array}$

$\begin{array}{ll}\text { Abstract } & 3\end{array}$

Table of Contents $\quad 4$

Introduction $\quad 5$

Executive Summary $\quad 6$

$\begin{array}{ll}\text { Experimental } & 7\end{array}$

$\begin{array}{lr}\text { Results and Discussion } & 8\end{array}$

$\begin{array}{ll}\text { Conclusion } & 17\end{array}$

$\begin{array}{ll}\text { List of Acronyms and Abbreviations } & 18\end{array}$

List of ODP Leg 204 Shipboard Scientific Party Members 19

In-Situ Sampling and Characterization of Naturally Occurring Marine Methane Hydrate Using the D/V JOIDES Resolution. 


\section{INTRODUCTION}

The primary accomplishments of the JOI Cooperative Agreement with DOE/NETL in this quarter were that: (1) Leg 204 scientific party members presented preliminary results and operational outcomes of ODP Leg 204 at the American Geophysical Union Fall meeting, which was held in San Francisco, CA; and, (2) a report was prepared by Dr. Gilles Guerin and David Goldberg from Lamont-Doherty Earth Observatory of Columbia University on their postcruise evaluation of the data, tools and measurement systems that were used for vertical seismic profiling (VSP) experiments during ODP Leg 204. The VSP report is provided herein.

Intermediate in scale and resolution between the borehole data and the 3-D seismic surveys, the Vertical Seismic Profiles (VSP) carried during Leg 204 were aimed at defining the gas hydrate distribution on hydrate ridge, and refining the signature of gas hydrate in the seismic data.

VSP surveys were attempted at five sites, following completion of the conventional logging operations. Bad hole conditions and operational difficulties did not allow to record any data in hole $1245 \mathrm{E}$, but vertical and constant offset VSP were successful in holes 1244E, 1247B and 1250F, and walk-away VSP were successfully completed in holes $1244 \mathrm{E}, 1250 \mathrm{~F}$ and $1251 \mathrm{H}$. Three different tools were used for these surveys.

The vertical VSP provided the opportunity to calculate interval velocity that could be compared and validated with the sonic logs in the same wells. The interval velocity profiles in Holes 1244E and 1247B are in very good agreement with the sonic logs.

Information about the Leg 204 presentations at the AGU meeting is included in a Topical Report, which has been provided to DOE/NETL in addition to this Quarterly Report. Work continued on analyzing data collected during ODP Leg 204 and preparing reports on the outcomes of Phase 1 projects as well as developing plans for Phase 2. 


\section{EXECUTIVE SUMMARY}

The primary accomplishments of the JOI Cooperative Agreement with DOE/NETL in this quarter were that: (1) Leg 204 scientific party members presented preliminary results and operational outcomes of ODP Leg 204 at the American Geophysical Union Fall meeting, which was held in San Francisco, CA; and, (2) a report was prepared by Dr. Gilles Guerin and David Goldberg from Lamont-Doherty Earth Observatory of Columbia University on their postcruise evaluation of the data, tools and measurement systems that were used for vertical seismic profiling (VSP) experiments during ODP Leg 204. The VSP report is provided herein.

Intermediate in scale and resolution between the borehole data and the 3-D seismic surveys, the Vertical Seismic Profiles (VSP) carried during Leg 204 were aimed at defining the gas hydrate distribution on hydrate ridge, and refining the signature of gas hydrate in the seismic data.

VSP surveys were attempted at five sites, following completion of the conventional logging operations. Bad hole conditions and operational difficulties did not allow to record any data in hole $1245 \mathrm{E}$, but vertical and constant offset VSP were successful in holes 1244E, 1247B and 1250F, and walk-away VSP were successfully completed in holes $1244 \mathrm{E}, 1250 \mathrm{~F}$ and $1251 \mathrm{H}$. Three different tools were used for these surveys.

The vertical VSP provided the opportunity to calculate interval velocity that could be compared and validated with the sonic logs in the same wells. The interval velocity profiles in Holes 1244E and 1247B are in very good agreement with the sonic logs.

Information about the Leg 204 presentations at the AGU meeting is included in a Topical Report, which has been provided to DOE/NETL in addition to this Quarterly Report. Work continued on analyzing data collected during ODP Leg 204 and preparing reports on the outcomes of Phase 1 projects as well as developing plans for Phase 2. 


\section{EXPERIMENTAL}

The primary accomplishments of the JOI Cooperative Agreement with DOE/NETL in this quarter were that: (1) Leg 204 scientific party members presented preliminary results and operational outcomes of ODP Leg 204 at the American Geophysical Union Fall meeting, which was held in San Francisco, CA; and, (2) a report was prepared by Dr. Gilles Guerin and David Goldberg from Lamont-Doherty Earth Observatory of Columbia University on their postcruise evaluation of the data, tools and measurement systems that were used for vertical seismic profiling (VSP) experiments during ODP Leg 204. The VSP report is provided herein.

Intermediate in scale and resolution between the borehole data and the 3-D seismic surveys, the Vertical Seismic Profiles (VSP) carried during Leg 204 were aimed at defining the gas hydrate distribution on hydrate ridge, and refining the signature of gas hydrate in the seismic data.

VSP surveys were attempted at five sites, following completion of the conventional logging operations. Bad hole conditions and operational difficulties did not allow to record any data in hole $1245 \mathrm{E}$, but vertical and constant offset VSP were successful in holes 1244E, 1247B and 1250F, and walk-away VSP were successfully completed in holes $1244 \mathrm{E}, 1250 \mathrm{~F}$ and $1251 \mathrm{H}$. Three different tools were used for these surveys.

The vertical VSP provided the opportunity to calculate interval velocity that could be compared and validated with the sonic logs in the same wells. The interval velocity profiles in Holes 1244E and 1247B are in very good agreement with the sonic logs. 


\section{RESULTS AND DISCUSSION}

The primary accomplishments of the JOI Cooperative Agreement with DOE/NETL in this quarter were that: (1) Leg 204 scientific party members presented preliminary results and operational outcomes of ODP Leg 204 at the American Geophysical Union Fall meeting, which was held in San Francisco, CA; and, (2) a report was prepared by Dr. Gilles Guerin and David Goldberg from Lamont-Doherty Earth Observatory of Columbia University on their postcruise evaluation of the data, tools and measurement systems that were used for vertical seismic profiling (VSP) experiments during ODP Leg 204.

Information about the Leg 204 presentations at the AGU meeting is included in a Topical Report, which has been provided to DOE/NETL in addition to this Quarterly Report. The report prepared by Dr. Gilles Guerin and David Goldberg from Lamont-Doherty Earth Observatory of Columbia University on their postcruise evaluation of the data, tools and measurement systems that were used for vertical seismic profiling (VSP) experiments during ODP Leg 204 is provided in the following paragraphs.

\section{General Overview of VSP Experiments on ODP Leg 204}

Intermediate in scale and resolution between the borehole data and the 3-D seismic surveys, the Vertical Seismic Profiles (VSP) carried during Leg 204 were aimed at defining the gas hydrate distribution on hydrate ridge, and refining the signature of gas hydrate in the seismic data.

VSP surveys were attempted at five sites, following completion of the conventional logging operations. Bad hole conditions and operational difficulties did not allow to record any data in hole $1245 \mathrm{E}$, but vertical and constant offset VSP were successful in holes 1244E, 1247B and 1250F, and walk-away VSP were successfully completed in holes $1244 \mathrm{E}, 1250 \mathrm{~F}$ and $1251 \mathrm{H}$. Three different tools were used for these surveys, which are summarized in Table 1 and Figure 1.

The vertical VSP allowed to calculate interval velocity that could be compared and validated with the sonic logs in the same wells. Figure 2 shows that, after a 5-sample smoothing, the interval velocity profiles in Holes $1244 \mathrm{E}$ and $1247 \mathrm{~B}$ are in very good agreement with the sonic logs. 


\section{Operations and data overview}

\section{Hole 1245E}

After completion of the standard wireline logs, rig up of the VSI for the VSP survey started on $08 / 15 / 02$ at 0830 local time. The plan was to conduct three types of survey during this run: vertical, constant offset and walk-away. The $R / V$ Maurice Ewing was navigating nearby to provide support for the constant offset and the walk-away surveys. Despite the generally good hole conditions that were observed during the standard log runs, it became clear after a few attempts that it would prove difficult to get a proper clamping for any of the shuttles, even less three. The average hole size (ranging from 12 to 16 in) exceeded the maximum operational hole size for the VSI (12 in). Multiple shots were fired from the Resolution and from the Ewing without ever recording a consistent signal, at any of the attempted depth. It was then decided to abort this run and to try to use the one-component WST to conduct at least a vertical VSP. When the VSI reached the rigfloor it appeared that the arms of the three shuttles had been damaged during our numerous clamping attempts. The WST was then lowered in the hole, but the geophone stopped soon to work properly and the tool was brought back to replace the geophone. During the following lowering, and despite the proper behavior of the WST, it became obvious that the hole was too large and the formation too soft to get a good clamping. The survey was aborted, and the final rig down was complete at 0200 on August 16, 2002.

\section{Hole 1251H}

After completion of conventional logs in Hole $1251 \mathrm{H}$, rig up for the VSP survey started at 0345 on August 18, 2002. The triple combo and FMS/Sonic calipers had shown that the hole was irregular, which suggested that the three component WST-3 would be the most likely to provide data. This tool had been flown in since the previous failure of the VSI in Site 1245. It proved again difficult to get a consistently good clamping. However the signal appeared of good enough quality to proceed with a systematic vertical and constant offset VSP. Stations were made over the entire hole every 7.5 meters, starting at 1405 mbrf. Satisfactory data were recorded for about $25 \%$ of the stations, the most consistently between 1350 and 1313 mbrf. After completion of the vertical/constant offset VSP, it was decided to attempt a walk-away VSP. It proved impossible to get good clamping at the initial target depths near the BSR, but a good station was found at 1320 mbrf and the Ewing shot two perpendicular lines, each taking $\sim 2$ hours. Final rig down was completed at 2030 on August 18, 2002. Figure 3 shows the data recorded by the three (geophone) components of the WST-3 on the first line (South to North) 


\section{Hole 1244E}

All the conventionnal logging runs indicated very good hole conditions in Hole 1244E. The WST-3 rig-up started at 0130 local time, 08/21/02, and the vertical/constant offset VSP started without difficulty from the bottom of the hole ( $1155 \mathrm{mbrf})$. Stations were made every 5 meters and the survey was completed without any problem, in excellent hole and sea conditions. Two walk-away stations, including two orthogonal lines each, were made at $1045 \mathrm{mbrf}$ and $1020 \mathrm{mbrf}$, respectively. The final rig down ended at 0100 local time, 08/22/2002. Figure 4 shows a general overview of the two lines recorded with the vertical component geophone of the WST-3 at $1020 \mathrm{mbrf}$ (=115 mbsf).

\section{Hole 1247B}

After completion of standard logs in Hole 1247B, rig-up of the WST-3 started at 0415, local time, 08/24/2002. Considering the good hole conditions, the plan was to conduct a complete survey including two walk-away stations. Initial tests before lowering the assembled tool string indicated serious problems, including the impossibility to properly close and open the arm, and it was decided to use the one component WST to perform only a vertical VSP. After lowering the tool, several unsuccessful attempts to record a decent signal indicated that the geophone was damaged. Because no spare geophone was available, and considering the extremely good hole and sea conditions, we decided to try using one of the shuttles of the VSI, which had been restored to its original configuration. The tool reached the bottom of the hole (1066 mbrf), and a vertical / constant offset survey was acquired without difficulties between $1060 \mathrm{mbrf}$ and $930 \mathrm{mbrf}$, with stations every 5 meters. After completion of this survey, it proved impossible to get a satisfactory station that would allow us to perform a walk-away VSP. Considering the poor quality of the signal, it was suspected that the tool had been damaged and it was brought back to the rig floor for inspection. This confirmed that the arm had been damaged, possibly while the tool was on station too close to the bottom of the pipe. It was decided to abort any further attempt in order to preserve the remaining shuttles for the final VSP survey in Site 1250. Final rig-down was complete at 1730, 08/24/2002.

\section{Hole 1250F}

After completion of the standard logs in Hole 1250F, rig-up of a the single-shuttle VSI started at 0610, August 26, 2002. The tool was lowered to the bottom of the hole ( 980 mbrf) and the vertical/constant-offset survey was recorded every 5 meters up to 890 mbrf. Coupling between the arm and the formation was poor in the upper part of the hole, and no reliable shots were recorded above 930 mbrf. Because of the generally poor signal, it 
was suspected that the tool had been damaged and it was brought back to the surface. Inspection showed that it was in working order, and it was lowered again to try to find possible walkaway stations. After systematic attempts along most of the hole, three walkaway surveys were recorded at 945 mbrf, 898 mbrf and 979 mbrf. Final rig down was completed at 0630 on August 27, 2002, a few hours before the Schlumberger VSP engineer was to leave the ship. Figure 5 shows the data recorded by the three geophone components of the VSI on the first line (South to North)

Table 1: Summary of VSP operations during Leg 204

\begin{tabular}{|c|c|c|c|c|c|}
\hline Hole & $\begin{array}{c}\text { VSP } \\
\text { spacing }(\mathrm{m})\end{array}$ & $\begin{array}{c}\text { VSP } \\
\text { interval } \\
\text { (mbsf) }\end{array}$ & Tool used & $\begin{array}{c}\text { Walkaway depth } \\
\text { (mbsf) }\end{array}$ & $\begin{array}{c}\text { Walkaway } \\
\text { shots } \\
\text { (S-N, W-E) }\end{array}$ \\
\hline $1251 \mathrm{H}$ & 7.5 & $85-185$ & WST-3 & 100 & 591,344 \\
\hline $1244 \mathrm{E}$ & 5 & $85-250$ & WST-3 & 140 & 563,560 \\
& & & & 115 & 474,543 \\
\hline $1247 \mathrm{~B}$ & 5 & $85-215$ & VSI & N/A & N/A \\
\hline $1250 \mathrm{~F}$ & 5 & $85-175$ & VSI & 90 & 445,412 \\
& & & & 140 & 461,458 \\
& & & & 170 & 424,337 \\
\hline
\end{tabular}




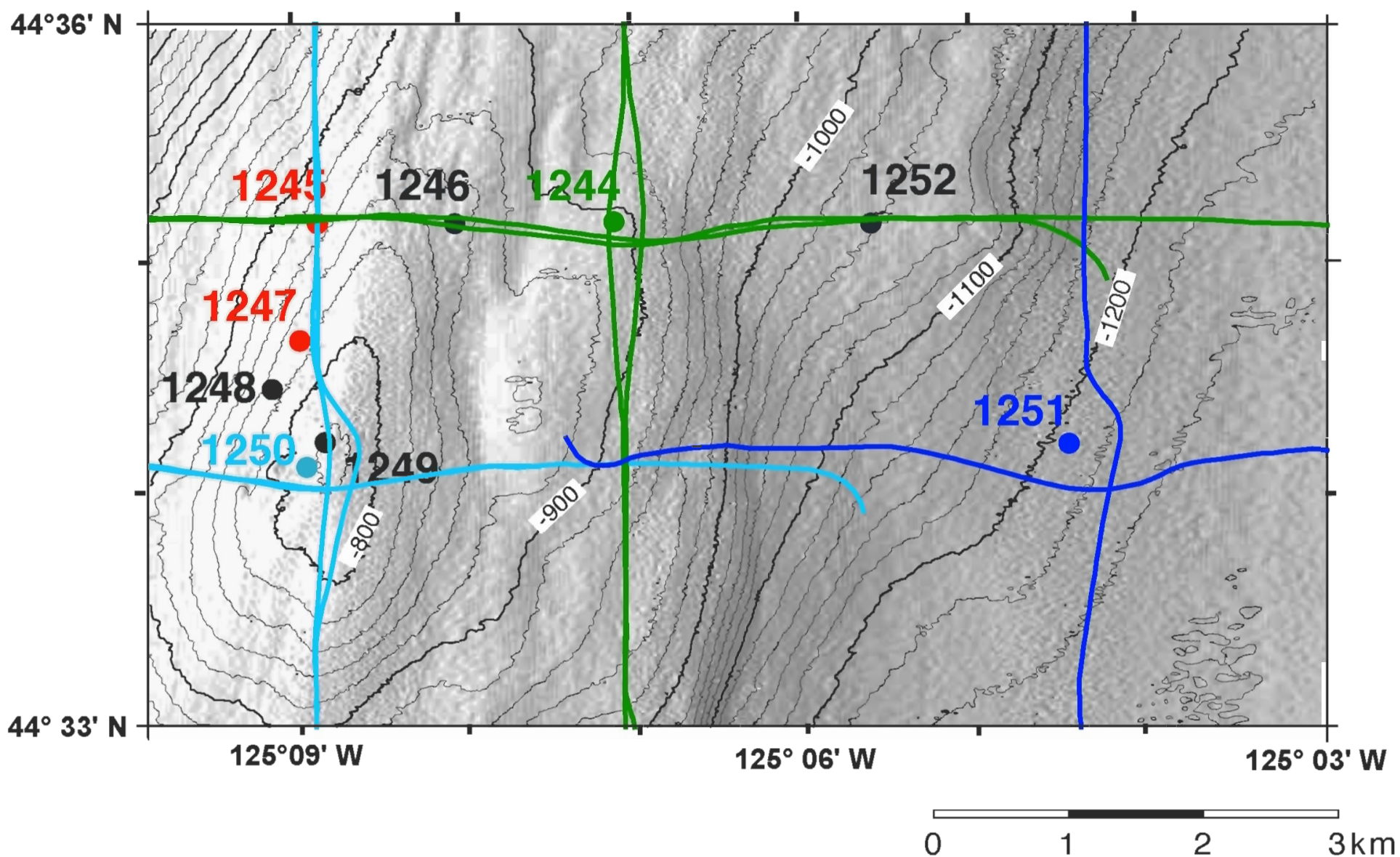

Figure 1: General overview of the VSP operations during Leg 204 around Hydrate Ridge. The sites in red indicate where vertical and constant offset VSP were recorded, but no walkaway. The colored lines dhow the path of the walkaway lines for the site of matching color. 

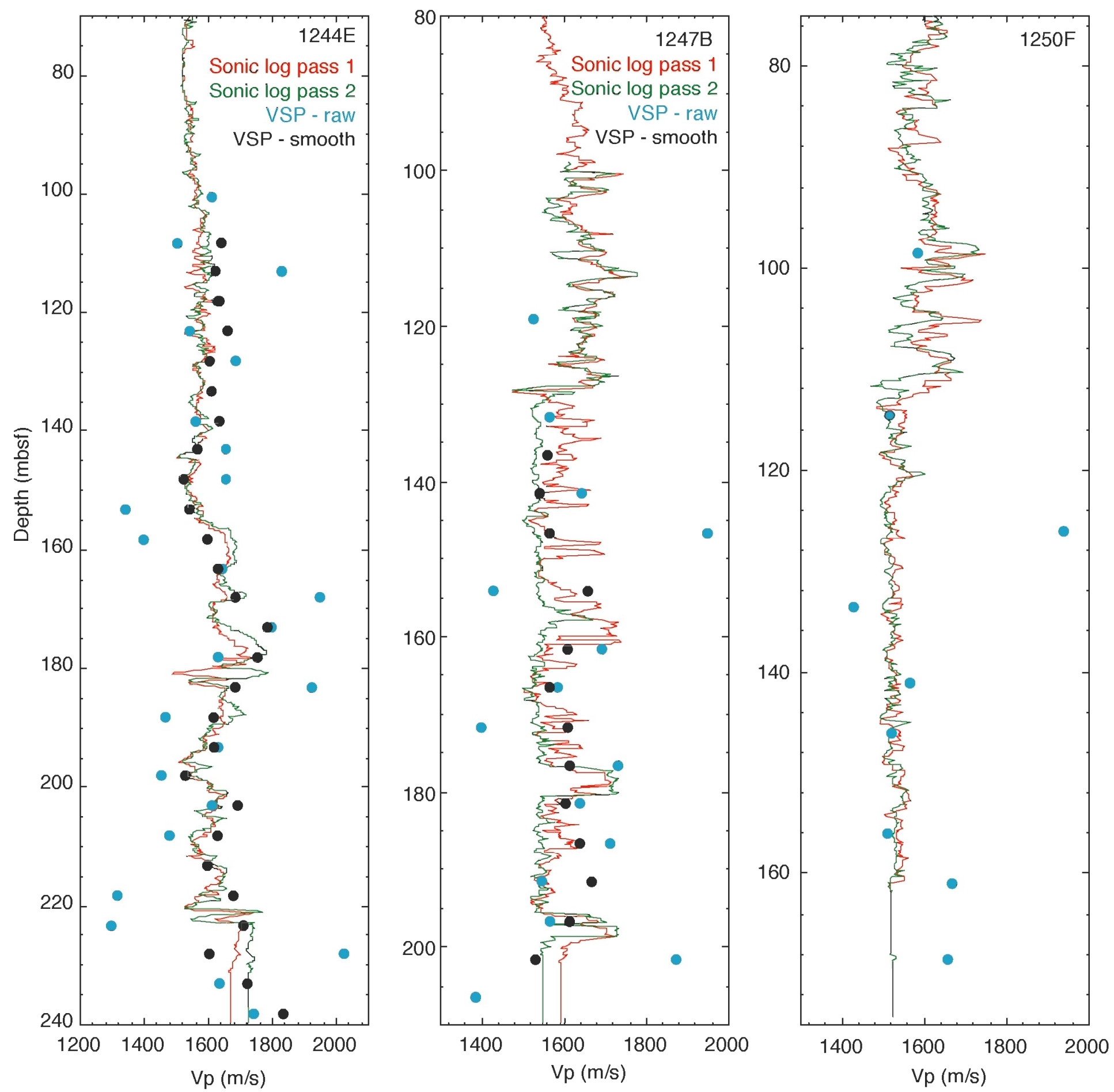

Figure 2: Comparison of the interval celocity values derived from the VSP with the logs in holes 1244E, 1247B and 1250F. In all figures, the first pass of the sonic log is in red, the second pass in green, the raw interval velocity in light blue and the 5-samples smoothed interval velocity in black 

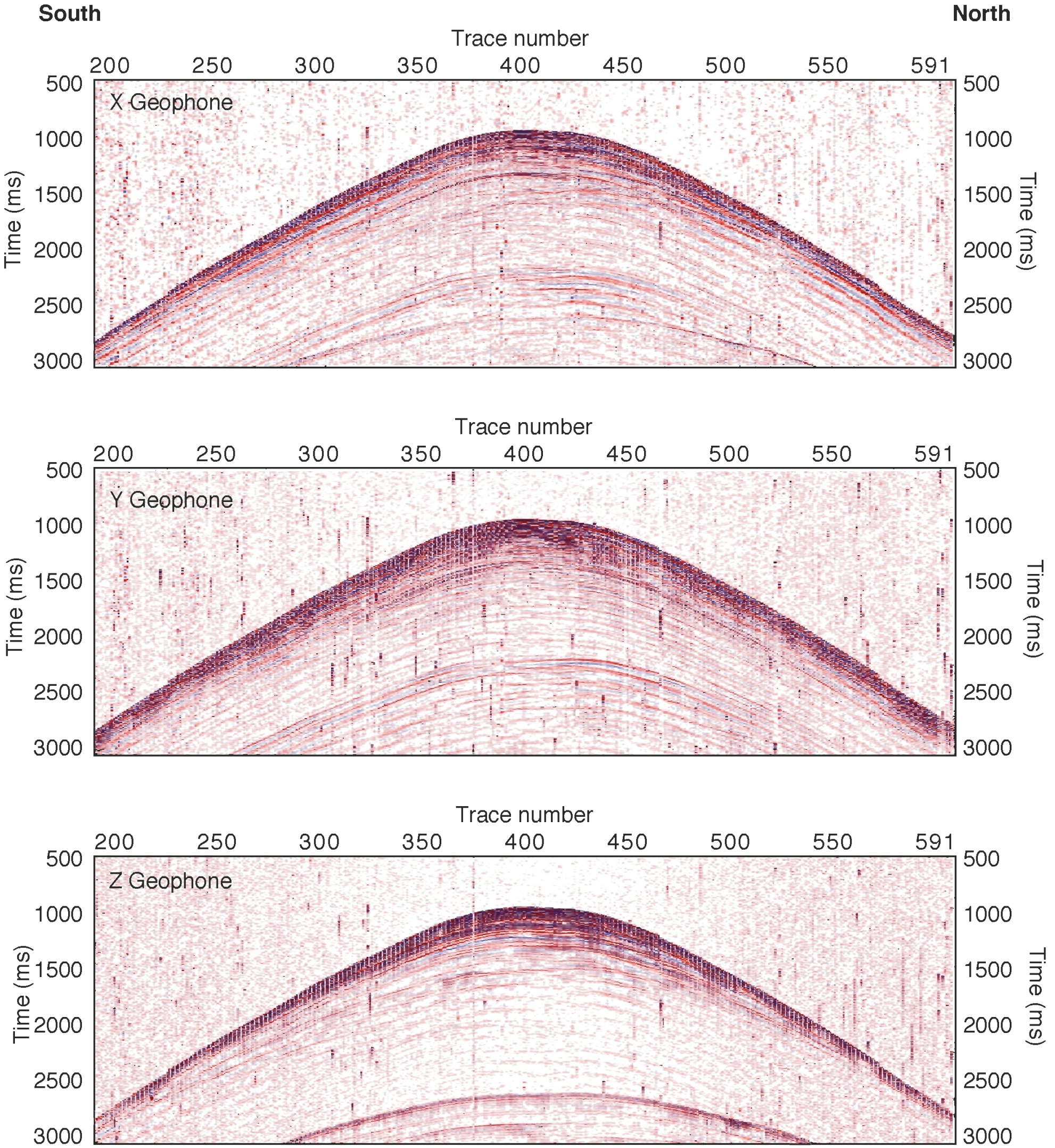

Figure 3: Walkaway line South-North recorded by the three geophones of the WST-3 at 1320 mbrf $(=100 \mathrm{mbsf})$ in Hole $1251 \mathrm{H}$. 


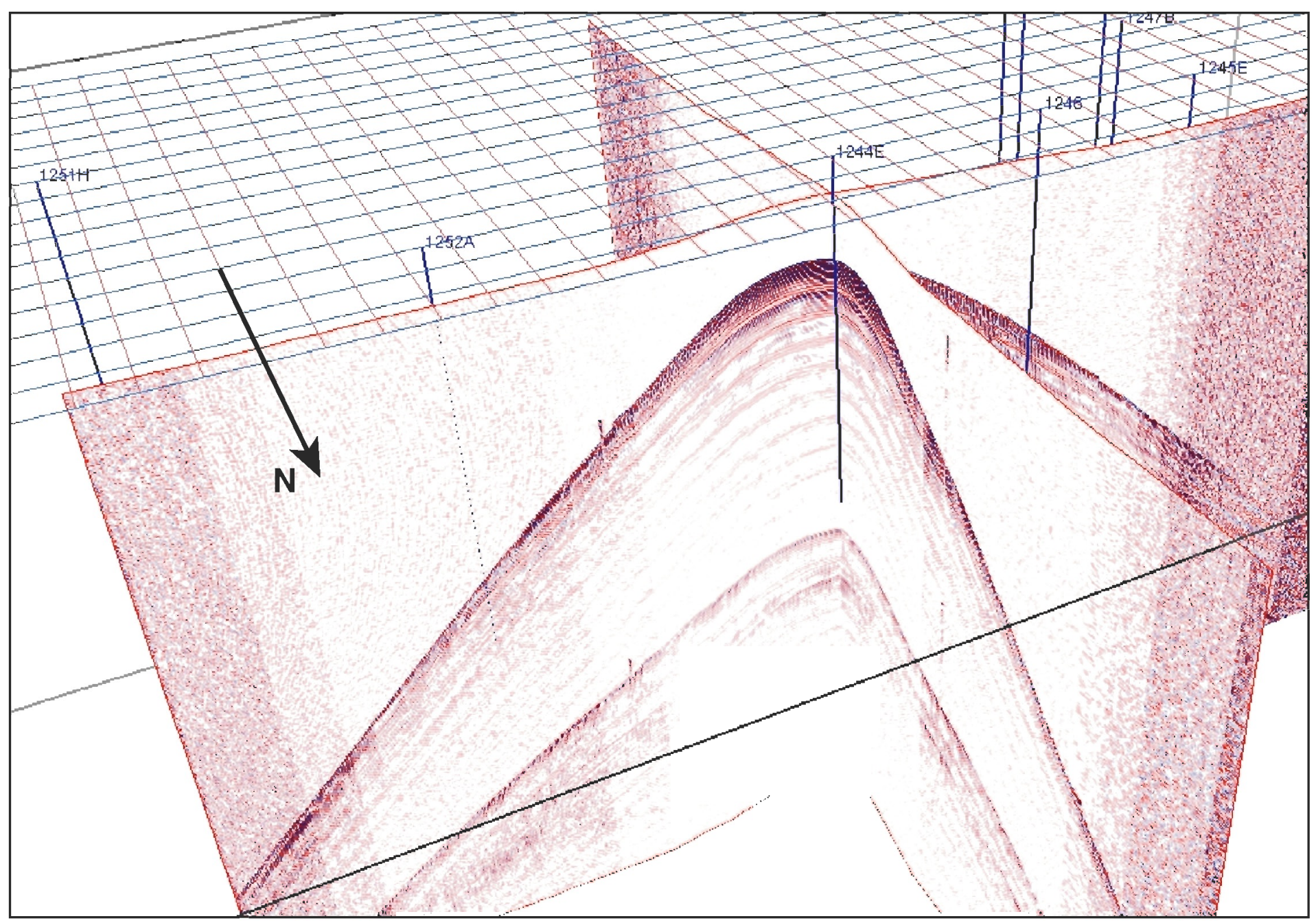

Figure 4: General overview of the two lines recorded with the vertical component geophone of the WST-3 at 1020 mbrf (=115 mbsf) in Hole 1244E. 

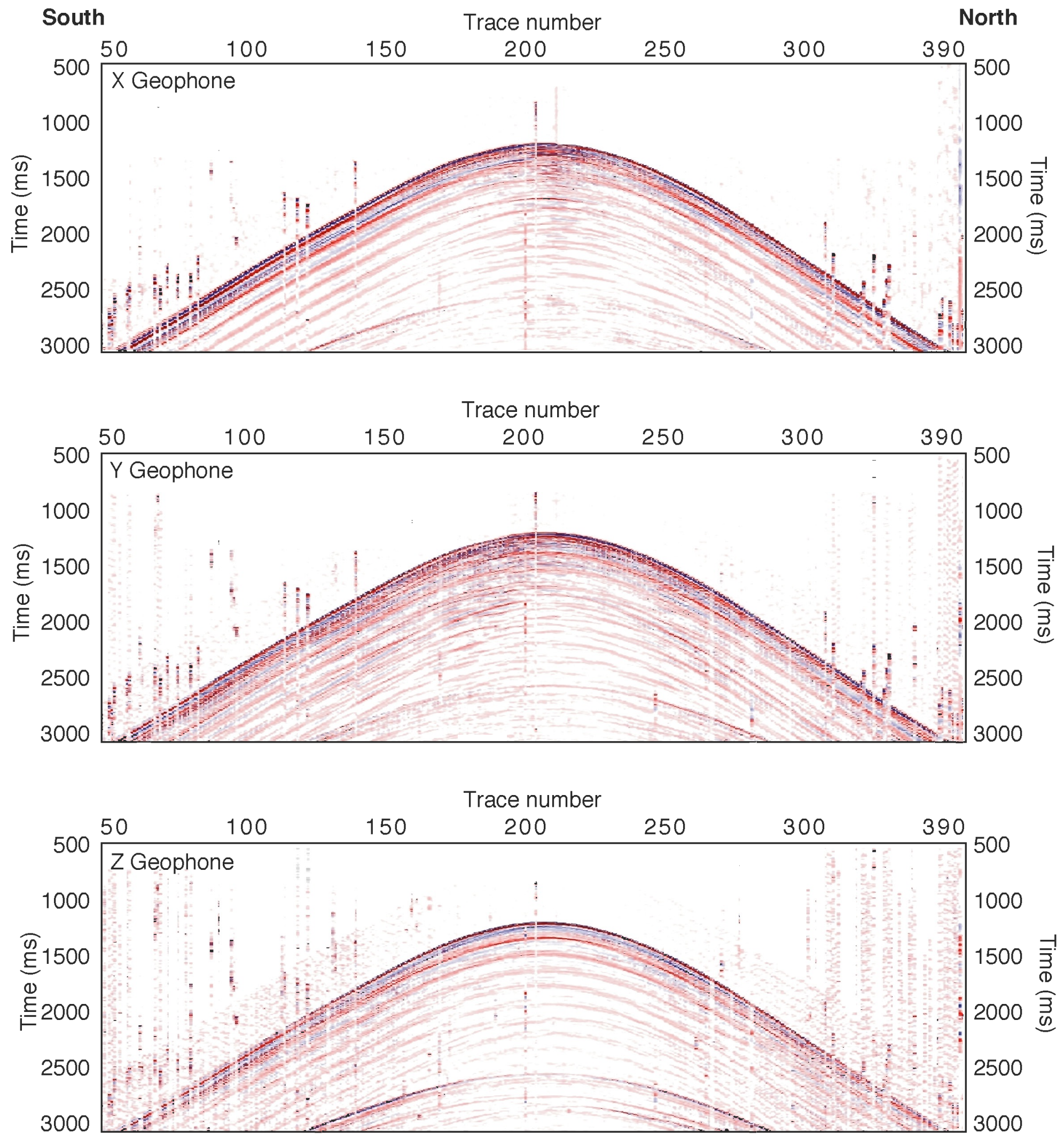

Figure 5: Walkaway line South-North recorded by the three geophones of the VSI at 979 mbrf $(=172$ mbsf) in Hole 1250F 


\section{CONCLUSION}

The primary accomplishments of the JOI Cooperative Agreement with DOE/NETL in this quarter were that: (1) Leg 204 scientific party members presented preliminary results and operational outcomes of ODP Leg 204 at the American Geophysical Union Fall meeting, which was held in San Francisco, CA (these results are summarized in a Topical Report submitted separately); and, (2) a report was prepared by Dr. Gilles Guerin and David Goldberg from Lamont-Doherty Earth Observatory of Columbia University on their postcruise evaluation of the data, tools and measurement systems that were used for vertical seismic profiling (VSP) experiments during ODP Leg 204.

Intermediate in scale and resolution between the borehole data and the 3-D seismic surveys, the Vertical Seismic Profiles (VSP) carried during Leg 204 were aimed at defining the gas hydrate distribution on hydrate ridge, and refining the signature of gas hydrate in the seismic data.

VSP surveys were attempted at five sites, following completion of the conventional logging operations. Bad hole conditions and operational difficulties did not allow to record any data in hole $1245 \mathrm{E}$, but vertical and constant offset VSP were successful in holes 1244E, 1247B and 1250F, and walk-away VSP were successfully completed in holes $1244 \mathrm{E}, 1250 \mathrm{~F}$ and $1251 \mathrm{H}$. Three different tools were used for these surveys.

The vertical VSP provided the opportunity to calculate interval velocity that could be compared and validated with the sonic logs in the same wells. The interval velocity profiles in Holes 1244E and 1247B are in very good agreement with the sonic logs.

Work continued on analyzing data collected during ODP Leg 204 and preparing reports on the outcomes of Phase 1 projects as well as developing plans for Phase 2. 


\section{LIST OF ACRONYMS AND ABBREVIATIONS}

$\begin{array}{ll}\text { APC } & \text { Advanced Piston Corer } \\ \text { APC-M } & \text { Advanced Piston Corer-methane tool } \\ \text { APC-T } & \text { Advanced Piston Corer-temperature tool } \\ \text { BHA } & \text { Bottom Hole Assembly } \\ \text { BSR } & \text { Bottom Simulating Reflector } \\ \text { DOE } & \text { Department of Energy } \\ \text { DVTP } & \text { Davis Villinger Temperature Probe } \\ \text { DVTP-P } & \text { Davis Villinger Temperature Probe with Pressure } \\ \text { FMMG } & \text { Fugro-McCleland Marine Geosciences } \\ \text { FPC } & \text { Fugro Pressure Corer } \\ \text { GHSZ } & \text { Gas Hydrate Stability Zone } \\ \text { HR } & \text { Hydrate Ridge } \\ \text { HRC } & \text { HYACE Rotary Corer } \\ \text { HYACE } & \text { Hydrate Autoclave Coring Equipment } \\ \text { HYACINTH } & \text { Deployment of HYACE tools In New Tests on Hydrates } \\ \text { IR-TIS } & \text { Infrared Thermal Imaging System } \\ \text { JOI } & \text { Joint Oceanographic Institutions } \\ \text { JOIDES } & \text { Joint Oceanographic Institutions for Deep Earth Sampling } \\ \text { LDEO } & \text { Lamont Doherty Earth Observatory (Columbia University) } \\ \text { L/L } & \text { Liters per Liter } \\ \text { LTC } & \text { Laboratory Transfer Chamber } \\ \text { LWD } & \text { Logging While Drilling } \\ \text { MBRF } & \text { Meters Below Rig Floor } \\ \text { MBSF } & \text { Meters Below Sea Floor } \\ \text { MH } & \text { Methane Hydrate } \\ \text { MPa } & \text { Mega-Pascals } \\ \text { MSCL-V } & \text { Multi-Sensor Core Logger - Vertical } \\ \text { NETL } & \text { National Energy Technology Laboratory } \\ \text { NSF } & \text { National Science Foundation } \\ \text { ODP } & \text { Ocean Drilling Program } \\ \text { ODP-LC } & \text { Ocean Drilling Program - Logging Chamber } \\ \text { PCS } & \text { Pressure Core Sampler } \\ \text { PSI } & \text { Pounds per Square Inch } \\ \text { RAB } & \text { Resistivity at the Bit } \\ \text { RAB-c } & \text { Resistivity at the Bit with Coring } \\ \text { RCB } & \text { Rotary Core Barrel } \\ \text { R/V } & \text { Research Vessel } \\ \text { TAMU } & \text { Texas A\&M University } \\ \text { XCB } & \text { Extended Core Barrel } \\ & \end{array}$




\section{List of ODP Leg 204 Shipboard Scientific Party Members}

Co-Chief Scientist - Gerhard Bohrmann (GEOMAR, Christian-Albrechts Universitat zu Kiel, Wischhofstrasse 1-3, Gebaude 4, Kiel 24148, Germany)

Co-Chief Scientist - Anne M. Trehu (College of Oceanic and Atmospheric Sciences, Oregon State University, 104 Oceanography Administration Building, Corvallis OR 97331-5503, USA)

ODP Staff Scientist - Frank R. Rack (Joint Oceanographic Institutions, Inc., 1755 Massachusetts Avenue, Northwest, Suite 700, Washington D.C. 20036, USA

Inorganic Geochemist - Walter S. Borowski (Earth Sciences Department, Eastern Kentucky University, 512 Lancaster Avenue, Roark 103, Richmond KY 40475-3102, USA)

Inorganic Geochemist - Hitoshi Tomaru (Graduate School of Science, University of Tokyo, Science Building 5, 7-3-1 Hong, Bunkyo-ku, Tokyo 113-0033, Japan)

Inorganic Geochemist - Marta E. Torres (College of Oceanic and Atmospheric Sciences, Oregon State University, 104 Oceanography Administration Building, Corvallis OR 97331-5503, USA)

Organic Geochemist - George E. Claypool (8910 West 2nd Avenue, Lakewood CO 80226, USA)

Organic Geochemist - Young-Joo Lee (Petroleum and Marine Resources Research Division, Korea Institute of Geoscience and Mineral Resources (KIGAM), 30 KajungDong, Yusong-Gu, Daejon 305-350, Korea)

Organic Geochemist - Alexei Milkov (Geochemistry and Environmental Research Group, Texas A\&M University, 833 Graham Road, College Station, TX 77845, USA)

PCS Scientist - Gerald R. Dickens (Department of Geology and Geophysics, Rice University, 6100 Main Street, Houston, TX 77005-1892, USA)

Logging Scientist - Timothy S. Collett (Branch of Petroleum Geology, U.S. Geological Survey, Denver Federal Center, Box 25046, MS 939, Denver CO 80225, USA)

Logging Scientist - Nathan Bangs (Institute for Geophysics, University of Texas at Austin, 4412 Spicewood Springs Road, Bldg. 600, Austin, TX 78759-8500, USA)

Geophysicist - Martin Vanneste (Department of Geology, Universitetet i Tromso, Dramsveinen 201, 9037 Tromso, Norway) 
Microbiologist - Melanie Holland (Department of Geologic Sciences, Box 871404, Arizona State University, Tempe, AZ 85287, USA)

Microbiologist - Mark E. Delwiche (Biotechnologies, Idaho National Engineering and Environmental Laboratory, 2525 N. Freemont St., Idaho Falls, ID 83415, USA)

Micropaleontologist (diatoms) - Mahito Watanabe (Geoscience Institute, Geological Survey of Japan, AIST, 1-1-1 Central 7 Higashi, Tsukuba 305-8567, Japan)

Physical Properties Specialist - Char-Shine Liu (Institute of Oceanography, National Taiwan University, P.O. Box 23-13, Taipei 106, Taiwan)

Physical Properties Specialist - Philip E. Long (Environmental Technology Division, Pacific Northwest National Laboratory, PO Box 999, Mail Stop K9-33, Richland WA 99352, USA)

Physical Properties Specialist - Michael Riedel (Geological Survey of Canada, Pacific Geoscience Centre, 9860 West Saanich Road, Sidney, BC V8L 4B2, Canada)

Physical Properties Specialist - Peter Schultheiss (GEOTEK Ltd., 3 Faraday Close, Drayton Fields, Daventry, Northants NN11 5RD, United Kingdom)

Sedimentologist - Eulalia Gracia (Institute of Earth Sciences (Jaume Almera), CSIC, Lluis Sole i Sabaris, 08028 Barcelona, Spain)

Sedimentologist - Joel E. Johnson (College of Oceanic and Atmospheric Sciences, Oregon State University, 104 Oceanography Admin. Bldg, Corvallis OR 97331, USA)

Sedimentologist - Xin Su (Center of Marine Geology, China University of Geosciences, Xueyuan Road 29, Beijing 100083, People's Republic of China)

Sedimentologist - Barbara Teichert (GEOMAR, Christian-Albrechts Universitat zu Kiel, Wischhofstrasse 1-3, Kiel 24148, Germany)

Sedimentologist/Structural Geologist - Jill L. Weinberger (Scripps Institution of Oceanography, University of California, San Diego, 9500 Gilman Drive, Mail Code 0208, San Diego CA 92093-0244, USA)

Logging Staff Scientist - David S. Goldberg (Lamont-Doherty Earth Observatory, Borehole Research Group, Columbia University, Route 9W, Palisades NY 10964, USA)

Logging Staff Scientist - Samantha R. Barr (Department of Geology, University of Leicester, University Road, Leicester LE1 7RH, United Kingdom) 
Logging Staff Scientist - Gilles Guèrin (Lamont-Doherty Earth Observatory, Columbia University, Borehole Research Group, Palisades, NY 10964, USA)

Operations Manager - Michael A. Storms (Ocean Drilling Program, Texas A\&M University, 1000 Discovery Drive, College Station TX 77845, USA)

Development Engineer - Derryl Schroeder (Ocean Drilling Program, Texas A\&M University, 1000 Discovery Drive, College Station TX 77845, USA)

Development Engineer - Kevin Grigar (Ocean Drilling Program, Texas A\&M University, 1000 Discovery Drive, College Station TX 77845, USA)

HYACINTH Engineer- Roeland Baas (Fugro Engineers, 2260 AG Leidschendam, The Netherlands)

HYACINTH Engineer - Floris Tuynder (Fugro Engineers, 2260 AG Leidschendam, The Netherlands)

HYACINTH Engineer - Felix Weise (Institute of Petroleum Engineering, Technical University of Clausthal, Clausthal, Germany)

HYACINTH Engineer - Thjunjoto (Maritime Technik, Technical University of Berlin, Berlin, Germany)

Piezoprobe Engineer - Terry Langsdorf (Fugro-McClelland Engineers, Houston, TX)

Peizoprobe Engineer - Ko-Min Tjok (Fugro-McClelland Engineers, Houston, TX)

Schlumberger Engineer - Kerry Swain (Schlumberger Offshore Services, 369 Tristar Drive, Webster, TX 77598, USA)

Schlumberger Engineer - Herbert Leyton (Schlumberger Offshore Services, USA)

Schlumberger Engineer - Stefan Mrozewski (Schlumberger Offshore Services, USA)

Schlumberger Engineer - Khaled Moudjeber (Schlumberger Offshore Services, USA)

Laboratory Officer - Brad Julson (Ocean Drilling Program, Texas A\&M University, 1000 Discovery Drive, College Station, TX 77845-9547, USA)

Assistant Laboratory Officer - Tim Bronk (Ocean Drilling Program, Texas A\&M University, 1000 Discovery Drive, College Station, TX 77845-9547, USA) 
Marine Lab Specialist: Yeoperson - Angie Miller (Ocean Drilling Program, Texas A\&M University, 1000 Discovery Drive, College Station, TX 77845-9547, USA)

Marine Lab Specialist Photography - John Beck (Ocean Drilling Program, Texas A\&M University, 1000 Discovery Drive, College Station, TX 77845-9547, USA)

Marine Lab Specialist Photography - Roy Davis (Ocean Drilling Program, Texas A\&M University, 1000 Discovery Drive, College Station, TX 77845-9547, USA)

Marine Lab Specialist (Temporary) - Jason Deardorf (Ocean Drilling Program, Texas A\&M University, 1000 Discovery Drive, College Station, TX 77845-9547, USA)

Marine Lab Specialist: Downhole Tools - Sandy Dillard (Ocean Drilling Program, Texas A\&M University, 1000 Discovery Drive, College Station, TX 77845-9547, USA)

Marine Lab Specialist: Chemistry - Dennis Graham (Ocean Drilling Program, Texas A\&M University, 1000 Discovery Drive, College Station, TX 77845-9547, USA)

Marine Laboratory Specialist: Curator - Jessica Huckemeyer (Ocean Drilling Program, Texas A\&M University, 1000 Discovery Drive, College Station TX 77845, USA)

Marine Computer Specialist - Margaret Hastedt (Ocean Drilling Program, Texas A\&M University, 1000 Discovery Drive, College Station TX 77845, USA)

Marine Lab Specialist: Chemistry - Brian Jones (Ocean Drilling Program, Texas A\&M University, 1000 Discovery Drive, College Station, TX 77845-9547, USA)

Marine Lab Specialist (Temporary) - Peter Kannberg (Ocean Drilling Program, Texas A\&M University, 1000 Discovery Drive, College Station, TX 77845-9547, USA)

Marine Electronics Specialist - Jan Jurie Kotze (Ocean Drilling Program, Texas A\&M University, 1000 Discovery Drive, College Station, TX 77845-9547, USA)

Marine Computer Specialist - Erik Moortgat (Ocean Drilling Program, Texas A\&M University, 1000 Discovery Drive, College Station TX 77845, USA)

Marine Electronics Specialist - Peter Pretorius (Ocean Drilling Program, Texas A\&M University, 1000 Discovery Drive, College Station, TX 77845-9547, USA)

Marine Lab Specialist: Physical Properties - John W.P. Riley (Ocean Drilling Program, Texas A\&M University, 1000 Discovery Drive, College Station, TX 77845-9547, USA) 
Marine Lab Specialist: Underway Geophysics - Johanna Suhonen (Ocean Drilling

Program, Texas A\&M University, 1000 Discovery Drive, College Station, TX 778459547, USA)

Marine Lab Specialist (Temporary) - Paul Teniere (Ocean Drilling Program, Texas A\&M University, 1000 Discovery Drive, College Station, TX 77845-9547, USA)

Marine Lab Specialist: X-ray - Robert Wheatley (Ocean Drilling Program, Texas A\&M University, 1000 Discovery Drive, College Station, TX 77845-9547, USA) 